\title{
Identification of Student Learning Styles Using the Dempster- Shafer Theory Algorithm
}

\author{
Rizki Wahyudi ${ }^{1 *}$, Noto Setyo Putro ${ }^{2}$ \\ ${ }^{1,2}$ Dept Informatics, Universitas Amikom Purwokerto, Jl. Letjend Pol. Soemarto, Karangjambu, Purwanegara, Kec. \\ Purwokerto Utara, Kabupaten Banyumas, Jawa Tengah 53127 \\ ${ }^{1}$ rizki.key@gmail.com*; notosetiyo8@gmail.com² \\ Corresponding Author*
}

\section{A R T I C L E I N F O}

\section{Article History:}

Receive January 1, 2020

Received January 22, 2020

Accepted February 12, 2020

Available Online February 23, 2020

\section{Keywords:}

Expert System

Dempster-Shafer Theory

student learning styles

ESDLC

\section{Kata Kunci:}

Sistem Pakar

Dempster-Shafer Theory

Gaya Belajar Siswa

ESDLC

Correspondence:

Telephon: 081329125484

E-mail: rizki.key@gmail.com

\section{ABSTRACT}

In the school environment, learning is the interaction between educators and students that is done consciously, planned both inside and outside the room to improve the ability of students. But a person's ability to learn, understand and absorb lessons differ in level. Some are fast, moderate, and some are very slow. Therefore, they often have to take different ways to understand the same information or lessons. This study aims to identify student learning styles by implementing the Dempster-Shafer Theory Algorithm to help teachers determine the learning model that is suitable for each student. Students who were the object of this study were students of SMA N 1 Klampok Purwareja. Dempster-Shafer Theory Algorithm can be used for the representation, combination and propagation of uncertainty, characteristics that are intuitively following the way of thinking of an expert, this algorithm can also distinguish the uncertainty and ignorance of the expert. So that research can be directed, the researcher uses the system development method ESDLC (Expert System Development Life Cycle) with the stages of Assessment, Knowledge Acquisition, Design, Testing, Documentation, and Maintenance. The results of this study an application of student learning style identification, making it easier for teachers to determine the learning model that is suitable for students.

\section{ABSTRAK}

Di lingkungan sekolah, belajar adalah interaksi antara pendidik dengan peserta didik yang dilakukan secara sadar, terencana baik didalam maupun di luar ruangan untuk meningkatkan kemampuan peserta didik. Namun kemampuan seseorang dalam belajar, memahami dan menyerap pelajaran berbeda tingkatnya. Ada yang cepat, sedang dan ada pula yang sangat lambat. Karenanya, mereka seringkali harus menempuh cara berbeda untuk bisa memahami sebuah informasi atau pelajaran yang sama. Penelitian ini bertujuan untuk mengidentifikasi gaya belajar siswa dengan mengimplementasikan Algoritme Dempster-Shafer Theory agar dapat membantu guru menentukan model pembelajaran yang cocok untuk masing-masing siswa. Siswa yang dijadikan objek penelitian ini adalah siswa SMA N 1 Klampok purwareja. Algoritme Dempster-Shafer Theory dapat digunakan untuk representasi, kombinasi dan propogasi ketidakpastian, karakteristik yang secara instutitif sesuai dengan cara berfikir seorang pakar, Algoritme ini juga dapat membedakan ketidakpastian dan ketidaktahuan dari pakar. Agar penelitian dapat terarah maka peneliti menggunakan metode pengembangan sistem ESDLC (Expert System Development Life Cycle) dengan tahapan Assesment, Knowledge Acquisition, Design, Testing, Documentation, dan Maintenance. Hasil penelitian ini sebuah aplikasi identifikasi gaya belajar siswa sehingga mempermudah guru untuk menentukan model pembelajaran yang cocok bagi siswa.

\section{Introduction}

Learning is a change in behaviour or appearance, with a series of activities, for example, by learning to read, observe, listen, imitate, and so forth. Learning will also be better if the subject of learning experiences or does it [1]. Everyone has a curiosity about something. These feelings and needs drive people always to learn. So, learning is an effort of people to know something that is not yet known, and everyone does it. 
In the school environment, learning is the interaction between educators and students that is done consciously, planned both inside and outside the room to improve the ability of students. Learning at school means that the interaction between the teacher and students is carried out consciously and planned, which is carried out both in the classroom and outside the classroom to improve student abilities [2].

But a person's ability to learn, understand and absorb lessons is different in level. Some are fast, moderate, and some are very slow. Therefore, they often have to take different ways to understand the same information or lessons. According to [3], student success in learning is influenced by external factors and internal factors. Internal factors are factors that originate from within students and one of them is learning style. Learning styles are a combination of ways to absorb and process information.

Based on the research [4] to identify student learning styles by building an expert system with a dynamic knowledge base Knowledge is obtained from various sources, including research conducted by experts in their fields and books related to learning styles. The drawing of conclusions in this expert system uses the forward chaining inference method. This expert system will display questions about the characteristics of the perceived learning style, then to get the final result. In the final result, the expert system will display the types of learning style characteristics possessed by students. To solve the problem of uncertainty in identifying student learning styles, the authors chose to use the DempsterShafer Theory Method.

Based on the research [5] Applying the Dempster Shafer Method to an expert system to identify Indihome (Indonesian Digital Home) service interruptions at PT Telkom to continue access to Indihome Services so that it can work well The results of this study is an expert system that diagnoses disturbances Indihome service. The system automatically provides diagnosis results by displaying the type of disorder and its solution based on the symptoms of the disorder experienced. This study concludes that an expert system using the Dempster Shafer method to handle data uncertainty when diagnosing Indihome service interruptions is very helpful in overcoming the problem of decreased service quality.

The choice of Dempster-Shafer Theory as a solution to identifying students' learning styles is because they can make representations, combinations and propagation of uncertainty, where this theory has several characteristics that are institutively following the way of thinking of an expert, but a strong mathematical basis. In this theory can also distinguish between uncertainty and ignorance.

The expert system will be built based on the Website because it is not the same as the desktop and android applications that must be installed, the Website with Responsive Design can also adjust the appearance according to the device used. According to Lutfi [6], Responsive Design is a technique used to make website layouts adjust to the appearance of the visitor's device. A responsive website is an approach that provides site design capabilities in adapting to site user behaviour and site environment. Which is based on screen size, screen orientation and site container. The way it works consists of a combination of frames and flexible appearance and the use of a creative CSS system. So if a user moves from his computer to another device, the site will change to the right resolution.

\section{Method}

Research stages are needed as a framework and guide the research process so that the series of research processes can be carried out in a directed, orderly and systematic way. 


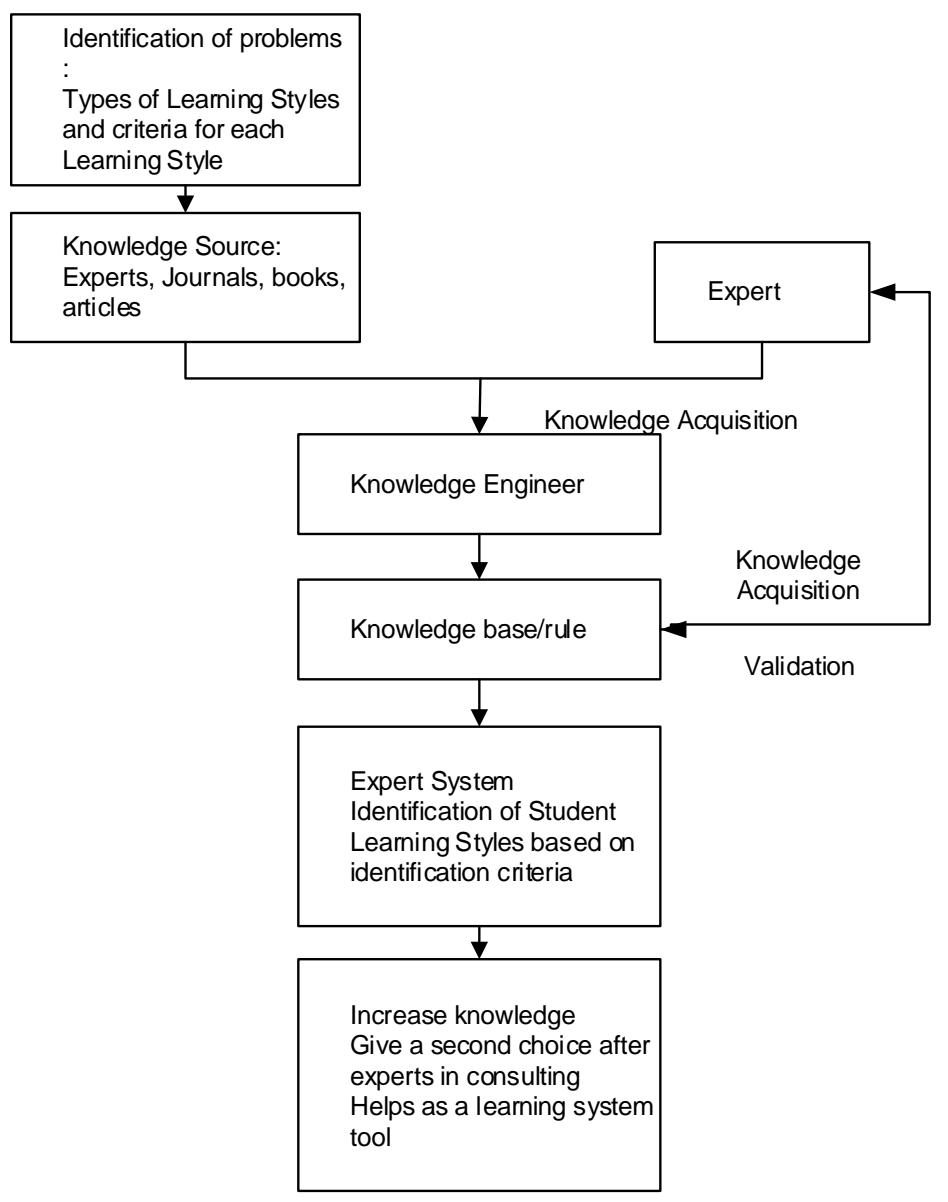

Figure 1. Research flow.

Figure 1. Research flow.In Figure 1. The framework explains the flow/stages of the research process and its results. This expert system to identify Student Learning Styles was developed using the Computer-Based System Engineering method based on the principles of the Expert System Development Cycle or ESDLC (Expert System Development Life Cycle). ESDLC consists of planning, knowledge acquisition, implementation, coding, evaluating (Figure 1).

The process of making an expert system application selection of tourist destinations using forward rulebased reasoning inference techniques is as follows:

a. Determine the object of research that will be applied in the expert system, namely SMA N 1 Klampok, Purwareja.

b. Collecting and identifying the types of learning styles, criteria for each type of learning style.

c. Analyse the types of learning styles that exist by exploring the criteria of each learning style. Furthermore, a search is carried out to ascertain whether the expert system can accommodate the criteria and types of learning styles by providing the best solution that must be taken or not. 


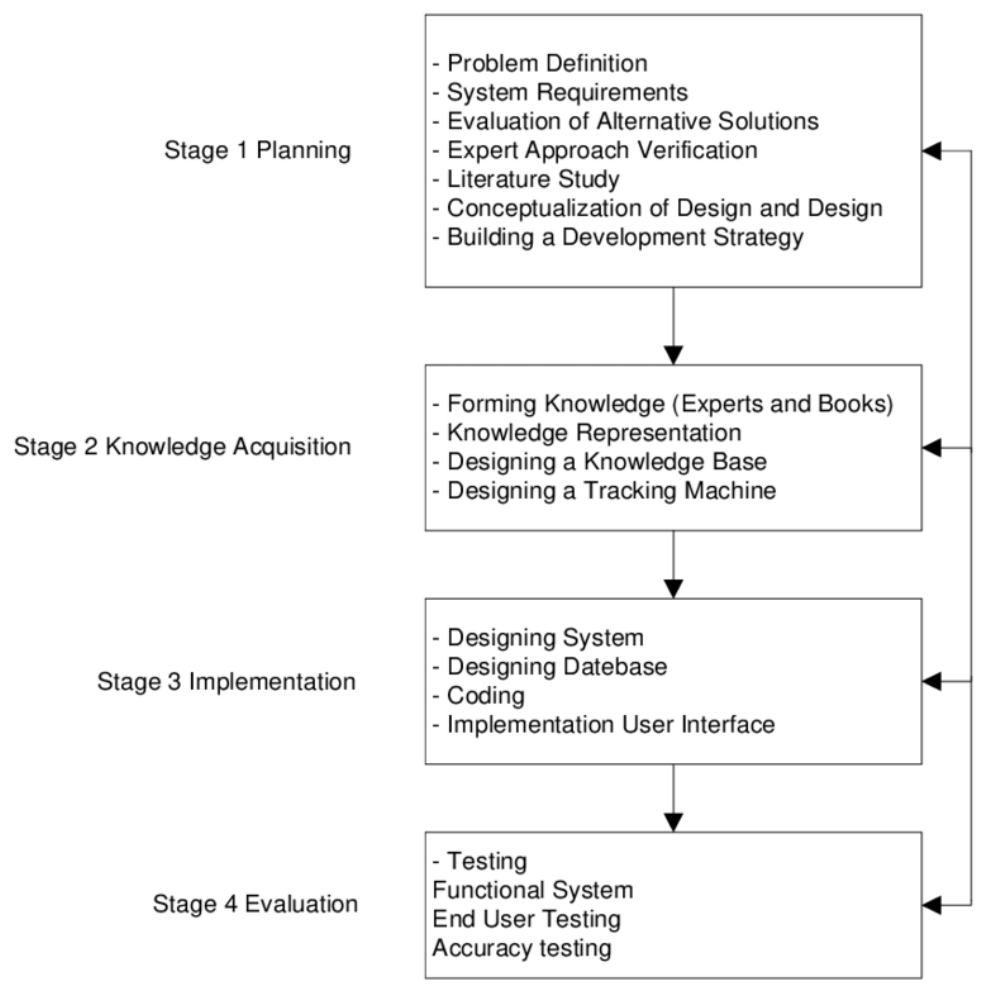

Figure 2. Model ESDLC (Expert System Development Life Cycle) [12]

d. The selection of experts whose knowledge will be acquired for interviewing and observing their work in the form of practical experience and understanding of the criteria and types of learning styles.

e. Make input and output design. Input expert systems in the form of learning style criteria that use the information provided by students, while the output is in the form of learning styles and suitable learning models.

f. The expert system architecture is technically the expert system design architecture identifies the learning style divided into three parts, namely interface, application and output. This interface can be used by users in interacting with expert system applications; this section is used to access the required information objects.

Bagian aplikasi dari sistem pakar ini berisi pengetahuan dan mesin inferensi. Semua gejalagejala dan jenis gaya belajar beserta aturannya disimpan dalam basis pengetahuan. Untuk menjembatani antara antar muka dan basis pengetahuan, maka mesin inferensi yang menjadi kemudi. Semua masukan yang berupa kriteria-kriteria gaya belajar akan dikaitkan dengan jenis gaya belajar yang sesuai. Keluaran dari sistem pakar ini adalah jenis gaya belajar dan model pembelajaran yang cocok untuk masing-masing siswa.

\section{a. Dempster-Shafer Theory}

The Dempster-Shafer method was first introduced by Dempster, who conducted uncertainty model experiments with range probabilities rather than as single probabilities. Then in 1976 Shafer published Dempster's theory in a book called Mathematical Theory of Evident. Dempster-Shafer Theory of Evidence shows a way to give the weight of confidence according to the facts collected. In this theory can distinguish between uncertainty and ignorance. Dempster-Shafer theory is a representation, combination and uncertainty propagation, where this theory has several characteristics that are institutively following the way of thinking of an expert, but a strong mathematical basis [9]. In general, the Dempster-Shafer theory is written at an interval:

[Belief, Plausibility] Belief (Bel) is a measure of the strength of evidence in supporting a set of propositions. If it is 0 , it indicates that there is no evidence, and if it is 1 , it indicates certainty. Plausibility 
(Pls) will reduce the level of certainty of the evidence. Plausibility is 0 to 1 . If you believe in $\mathrm{X}$ ', you can say that $\mathrm{Bel}\left(\mathrm{X}^{\prime}\right)=1$, so the formula above is from $\mathrm{Pls}(\mathrm{X})=0$.

According to Giarratano and Riley, the Belief function can be formulated and shown in equation (1):

$$
\operatorname{Bel}(X)=\sum_{Y C X} m(Y)
$$

And Plausibility is notated in equation (2):

$$
P l s(X)=1-\operatorname{Bel}(X)=1-\sum_{Y C X} m(Y)
$$

Where:

$$
\begin{aligned}
& \operatorname{Bel}(\mathrm{X})=\operatorname{Belief}(\mathrm{X}) \\
& \operatorname{Pls}(\mathrm{X})=\text { Plausibility }(\mathrm{X}) \\
& \mathrm{m}(\mathrm{X})=\text { mass function from }(\mathrm{X}) \\
& \mathrm{m}(\mathrm{Y})=\text { mass function from }(\mathrm{Y})
\end{aligned}
$$

The Dempster-Shafer theory states that there is a frame of discourse denoted by the symbol $(\Theta)$. A frame of Decrement is the universe of discussion of a set of hypotheses so that it is often referred to as the environment shown in equation (3):

$$
\Theta=\{\theta 1, \theta 2, \ldots \theta \mathrm{N}\}
$$

Where:

$$
\begin{aligned}
& \Theta=\text { frame of decrement or environment } \\
& \theta 1, \ldots, \theta \mathrm{N}=\text { element } / \text { in environment }
\end{aligned}
$$

The environment contains elements that describe possibilities as answers, and there is only one that will match the answers needed. This possibility in Dempster-Shafer theory is called the power set and notated by $P(\Theta)$. Each element in this power set has an interval value between 0 to 1 .

$$
\mathrm{m}: \mathrm{P}(\Theta)[0,1]
$$

So that it can be formulated in equation (4):

$$
\sum_{X \in P(0)} m(Y)=1
$$

With:

$$
\begin{aligned}
& P(\Theta)=\text { power set } \\
& m(X)=\text { mass function }(X)
\end{aligned}
$$

\section{Results and Discussion}

From the knowledge base collected, it can be grouped into 3 tables that are needed in analyzing. The tables used are the characteristic table (1), the problem table (2), and the table of rules that explain the relationship between the rules of the rule (3) The characteristics included:

Table 1. Learning style

\begin{tabular}{cc}
\hline Code & Learning style \\
\hline GB01 & Visual \\
GB02 & Auditori \\
\hline
\end{tabular}




\section{GB03 Kinestik}

In Figure 1. There are three student learning styles and their explanations:

\section{Visual Learning Style}

Visual Learning Style emphasises visual acuity. That is, concrete evidence must be shown first so that they understand Learning styles like this rely on vision or see the evidence first and then can trust it. Some characteristics are typical of people who like this visual learning style. First is the need to see something information/lessons) visually to know it or understand it, second has a strong sensitivity to colour, third has an adequate understanding of artistic problems, fourth has difficulty in dialogue directly, fifth is too reactive to sound, six difficult to follow suggestions oral, the seventh often misinterpret words or sayings.

\section{Auditory Learning Style}

Auditory learning styles (Auditory Learners) rely on hearing to be able to understand and remember them. The characteristics of learning models such as these place hearing as the primary means of absorbing information or knowledge. That is, we must listen to, then we can remember and understand the information. The first character of people who have this learning style is that all information can only be absorbed through hearing, the second has difficulty absorbing information in written form directly, the third has difficulty writing or reading.

\section{Kinesthetic Learning Style}

Kinesthetic Learners (Kinesthetic Learners) require that the individual concerned touch something that provides certain information so that he can remember it. Of course, there are some characteristics of learning models like this that not everyone can do. The first character is placing the hand as the main recipient of information so that it can continue to remember it. Only by holding it, someone who has this style can absorb information without having to read the explanation.

Tabel 1. Student Character

\begin{tabular}{ll}
\hline Code & \multicolumn{1}{c}{ Student Character } \\
\hline K01 & Often say something that looks delicious \\
K02 & Often say something that sounds good \\
K03 & Often say something that tastes good \\
K04 & Easy to remember things to see \\
K05 & Easy to remember what was heard \\
K06 & Easy to remember things to do \\
K07 & More impressed with people, environment and face \\
K08 & More impressed by the sound and name \\
K09 & More impressed with events, emotions and events \\
K10 & Liked the painting \\
K11 & Liked the music \\
K12 & Likes sports \\
K13 & Tend to pay attention to people on the face and clothes worn \\
K14 & Tends to pay attention to people in their conversation \\
K15 & Tends to pay attention to people in their behaviour and movements
\end{tabular}


K16 Happy to memorise something by writing

K17 It's good to memorise something by repeating words in a loud voice

K18 Like to memorise something by walking

K19 In explaining, it tends to make streaks on the paper

K20 In explaining, it tends to convey verbally

K21 In explaining, tend to use hand movements

K22 Easily disturbed by messy items in the vicinity

K23 Easily disturbed by noisy sounds

K24 Easily disturbed by moving objects

K25 Very interested in colour

K26 Very interested in sound

K27 Very interested in body movements

K28 analysing something by scribbling

K29 Analyse something by talking repeatedly

K30 Analysing something by imagining something

K31 It's hard to study long if the notes are not neat

K32 Difficulty concentrating when there is a commotion

K33 It's hard to sit still and calm

K34 The tendency to start opinion sentences: "according to what I saw."

K35 The tendency to start opinion sentences: "according to what I heard."

K36 The tendency to start opinion sentences: "according to what I did."

K37 Likes to be taught by the teacher by describing objects on the board

K38 Likes to be taught by teachers who explain in detail

K39 Likes to be taught by the teacher by practising the object being discussed

K40 Like to see the scenery / background / background when watching a movie

K41 Like to hear dialogue when watching movies

K42 Likes to observe the actors acting when watching a movie

K43 Very interested in the product model (design and color) that will be purchased

K44 Easily attracted to a product when there is a good explanation from the seller

K45 Like to try the product to be purchased

K46 Speak with a fast tempo

K47 Speak with moderate tempo

K48 Talk with a slow tempo 
K49 Following the illustration how to arrange objects or tools

K50 Listening to people read out instructions for assembling objects or tools

K51 Try objects or tools immediately without following instructions

K52 When reading a book, trace each word with the index finger

K53 When reading a book, read it calmly, quickly and diligently

K54 When reading a book while moving his lips and say it

K55 When angry, visible from facial expressions

K56 When angry, visible from the voice intonation

K57 When angry, visible from body movements

K58 Pay attention to the teacher's face when he talks / explains

K59 Just listen when the teacher explains

K60 When the teacher explains, hands cannot stand still, playing ballpoint

Tabel 3. Relasi

\begin{tabular}{|c|c|c|c|c|}
\hline Kode & Visual & Auditori & Kinestetik & Bobot CF \\
\hline K01 & 1 & & & 0,8 \\
\hline K02 & & 1 & & 0,7 \\
\hline K03 & & & 1 & 0,8 \\
\hline K04 & 1 & & & 0,8 \\
\hline K05 & & 1 & & 0,8 \\
\hline K06 & & & 1 & 0,8 \\
\hline K07 & 1 & & & 0,8 \\
\hline K08 & & 1 & & 0,5 \\
\hline K09 & & & 1 & 0,6 \\
\hline K10 & 1 & & & 0,7 \\
\hline K11 & & 1 & & 0,7 \\
\hline K12 & & & 1 & 0,7 \\
\hline K13 & 1 & & & 0,9 \\
\hline K14 & & 1 & & 0,8 \\
\hline K15 & & & 1 & 0,6 \\
\hline K16 & 1 & & & 0,8 \\
\hline K17 & & 1 & & 0,8 \\
\hline K18 & & & 1 & 0,6 \\
\hline K19 & 1 & & & 0,8 \\
\hline K20 & & 1 & & 0,8 \\
\hline K21 & & & 1 & 0,5 \\
\hline K22 & 1 & & & 0,4 \\
\hline K23 & & 1 & & 0,5 \\
\hline K24 & & & 1 & 0,4 \\
\hline K25 & 1 & & & 0,6 \\
\hline K26 & & 1 & & 0,5 \\
\hline K27 & & & 1 & 0,5 \\
\hline K28 & 1 & & & 0,7 \\
\hline K29 & & 1 & & 0,8 \\
\hline K30 & & & 1 & 0,7 \\
\hline K31 & 1 & & & 0,6 \\
\hline K32 & & 1 & & 0,8 \\
\hline
\end{tabular}


Vo1. 1, No. 1, February 2020, pp. 40-51

\begin{tabular}{|c|c|c|c|c|}
\hline K33 & & & 1 & 0,6 \\
\hline K34 & 1 & & & 0,8 \\
\hline K35 & & 1 & & 0,8 \\
\hline K36 & & & 1 & 0,7 \\
\hline K37 & 1 & & & 0,7 \\
\hline K38 & & 1 & & 0,8 \\
\hline K39 & & & 1 & 0,7 \\
\hline K40 & 1 & & & 0,4 \\
\hline K41 & & 1 & & 0,6 \\
\hline K42 & & & 1 & 0,6 \\
\hline K43 & 1 & & & 0,6 \\
\hline K44 & & 1 & & 0,4 \\
\hline K45 & & & 1 & 0,5 \\
\hline K46 & 1 & & & 0,8 \\
\hline K47 & & 1 & & 0,6 \\
\hline K48 & & & 1 & 0,6 \\
\hline K49 & 1 & & & 0,6 \\
\hline K50 & & 1 & & 0,4 \\
\hline K51 & & & 1 & 0,5 \\
\hline K52 & 1 & & & 0,7 \\
\hline K53 & & 1 & & 0,8 \\
\hline K54 & & & 1 & 0,8 \\
\hline K55 & 1 & & & 0,7 \\
\hline K56 & & 1 & & 0,7 \\
\hline K57 & & & 1 & 0,6 \\
\hline K58 & 1 & & & 0,8 \\
\hline K59 & & 1 & & 0,6 \\
\hline K60 & & & 1 & 0,6 \\
\hline
\end{tabular}

The weight of confidence in this system is the weight of the CF value inputted by the expert. In the system there are 20 questions, where for each answer in the question there are elements of learning style characters. Students can only choose one answer that matches their character. When students choose the answer, automatically the weight of the CF character value will be stored by the system. For more details, a manual calculation is provided in the case examples based on the answers from the questionnaire (attached) given to students presented in Table 4. below:

Table 4. Calculation (random)

\begin{tabular}{rrcc}
\hline No & Kriteria & Bobot \\
\hline 1 & K02 & 0,7 \\
2 & K04 & 0,8 \\
3 & K09 & 0,6 \\
4 & K11 & 0,7 \\
5 & K13 & 0,9 \\
6 & K16 & 0,8 \\
7 & K21 & 0,5 \\
8 & K22 & 0,4 \\
9 & K27 & 0,5 \\
10 & K28 & 0,7 \\
11 & K31 & 0,6 \\
12 & K35 & 0,8 \\
13 & K38 & 0,8 \\
14 & K41 & 0,6
\end{tabular}




\begin{tabular}{lll}
\hline 15 & K44 & 0,4 \\
16 & K47 & 0,6 \\
17 & K51 & 0,5 \\
18 & K54 & 0,8 \\
19 & K55 & 0,7 \\
20 & K58 & 0,8 \\
\hline
\end{tabular}

Explanation of the inference machine with the dempster shafer method can be explained by manual calculation as applied to formula (1) as follows:

\begin{tabular}{|c|c|c|c|c|c|c|c|}
\hline & $\mathbf{K 5 8}$ & $\mathrm{V}$ & & & $\theta$ & & \\
\hline M1 & & 0,8 & & & 0,2 & & \\
\hline V & 0,794549 & & $\mathrm{~V}$ & 0,635639 & & $\mathrm{~V}$ & 0,15891 \\
\hline A & 0,198586 & & $\varnothing$ & 0,158869 & & A & 0,039717 \\
\hline K & 0,006797 & & $\varnothing$ & 0,005437 & & $\mathrm{~K}$ & 0,001359 \\
\hline$\theta$ & $6,87 \mathrm{E}-05$ & & $\mathrm{~V}$ & $5,49 \mathrm{E}-05$ & & $\theta$ & $1,37 \mathrm{E}-05$ \\
\hline
\end{tabular}

$\begin{array}{lll}\text { M1 } & \text { V } & 0,990831 \\ & \text { A } & 0,047526 \\ & \text { K } & 0,001627 \\ & \theta & 1,64 \mathrm{E}-05\end{array}$

From the results of all the manual calculations of the Dempster Shafer method with three input characteristics, the highest value obtained from M19 is that the student is in the category that matches the visual learning model with a confidence value of $95 \%$. This value is in accordance with calculations through an expert system that has been developed in figure (4). It should be underlined that the confidence value chosen is based on the largest value of each density. This means that a low confidence score does not mean low confidence in the results of the diagnosis and vice versa.

\section{User Interface Application Identification of Student Learning Styles}

Student Learning Style Identification Application consists of two parts of the user (user interface) and administrator, in the user section, can identify student learning styles by entering the characters of students can be seen in Figure 3. while the administrator part contains input Criteria Data, Learning Style Data and Rule Data can be seen in Figure 4. 


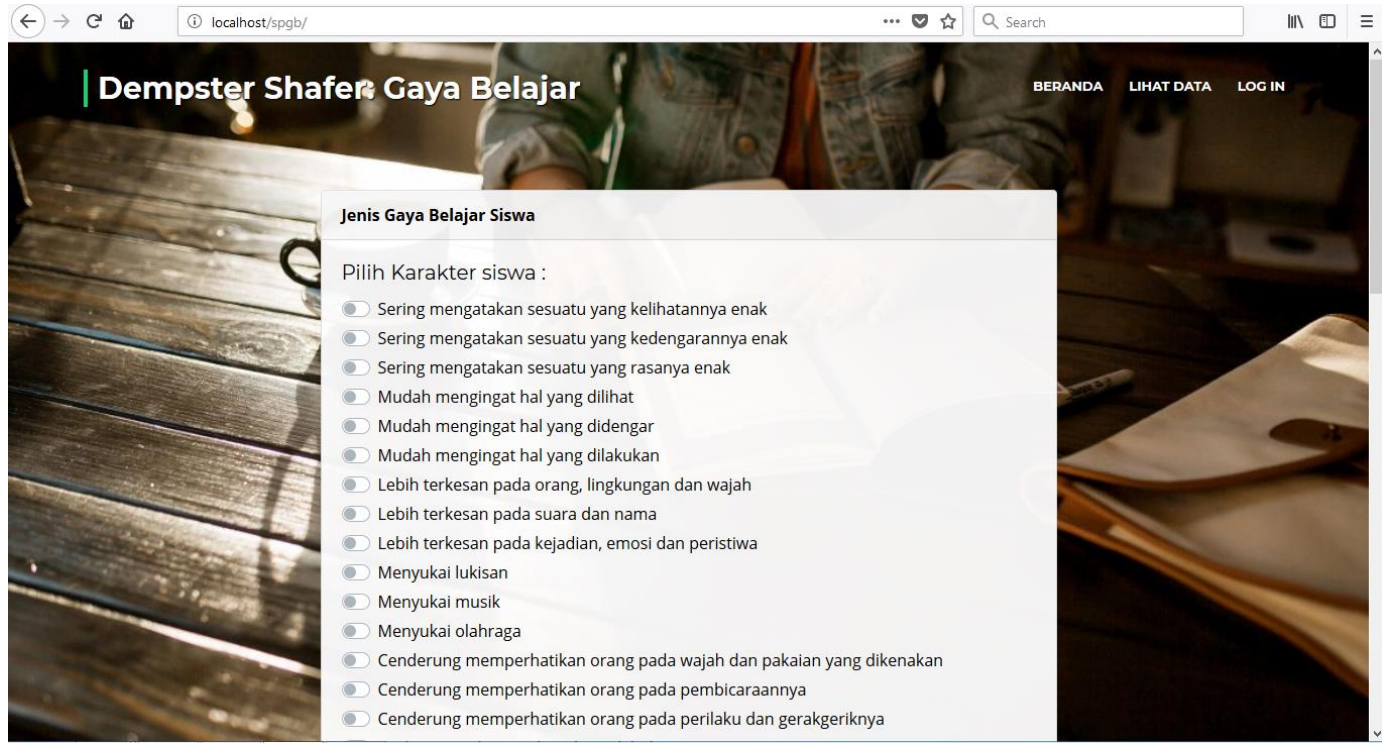

Figure 3. User Form

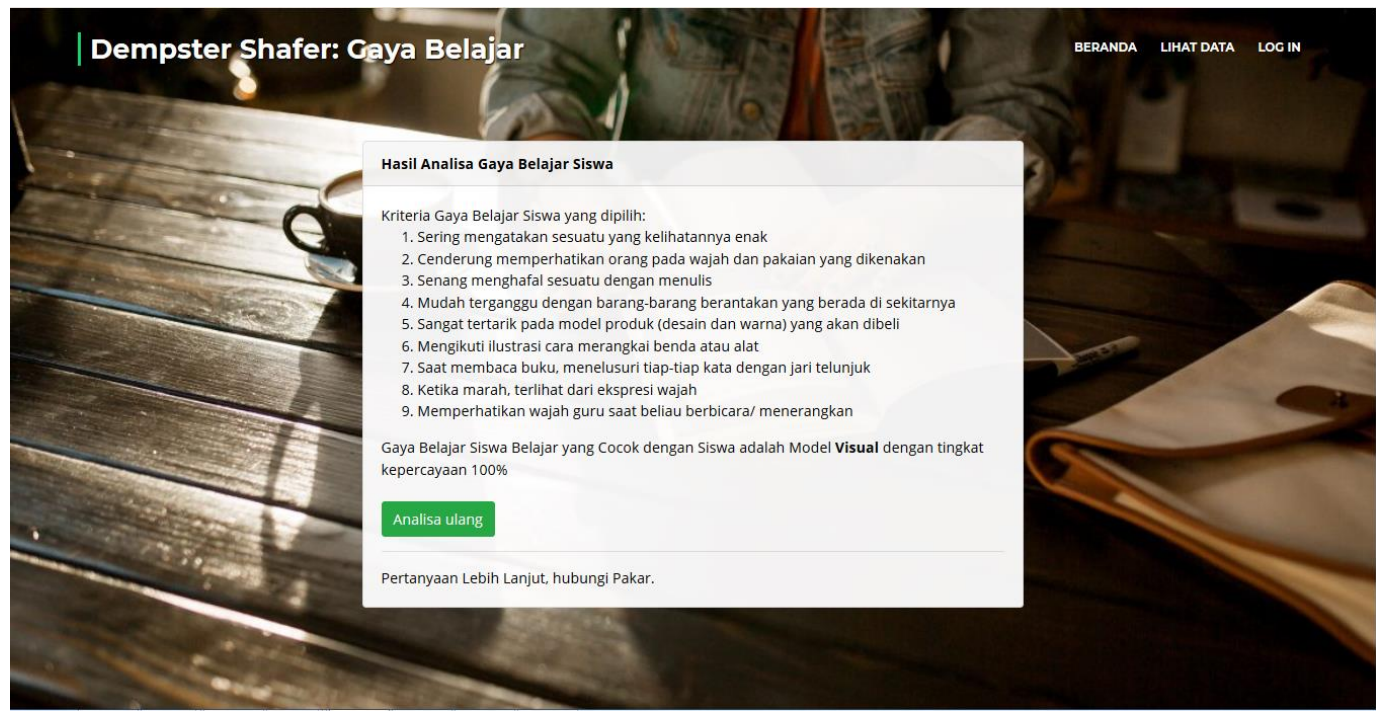

Figure 4. Analysis Results

\section{Conclusion}

Based on the discussion in the previous chapter it can be concluded that the application of learning model identification using Demster Shafer Theory has been successfully built, the application can identify student learning styles by tracing the characters of students. Suggestions for future research need to be reviewed again related to the learning model and character of students, to see the comparison of identification accuracy levels can be compared using other algorithms, and so that it can be accessed easily by users can consider by developing an Android application.

\section{References}

[1] Sardiman. (2007). Interaksi dan Motivasi belajar Mengajar. Jakarta: Rajagrafindo Persada.

[2] Muhamad Afandi, Evi Chamalah \& Oktarina Puspita Wardani (2013) Metode Dan Metode Pembelajaran Di Sekolah. UNISSULA Press 2013.

[3] DePorter, Bobbi \& Hernacki, Mike. 2006. Quantum Learning: Membiaasakan Belajar Nyaman \& MEnyenangkan. Bandung: PT.Mizah Pustaka.

[4] Ibrohim, Muhamad dan Purwanty, Novi (2017). Rancang Bangun Aplikasi Identifikasi Gaya Belajar Siswa Dengan MetodeForward Chaining (Studi Kasus: Sekolah Dasar Negeri Sumampir). Jurnal ProTekInfo Vol. 4 Agustus, 19-28. 
[5] Endang Lestari \& Emilya Ully Artha (2017). Sistem Pakar dengan Metode Dempster Shafer untuk Diagnosis Gangguan Layanan INDIHOME di PT TELKOM Magelang. Jurnal Khazanah. Vol. 3 No. 1 | Juni 2017.

[6] Lutfi, A. A., \& Wahyudi, R. (2017). Aplikasi Tracer Study Berbasis Website Responsive Pada Fakultas Pertanian Universitas Jendral Soedirman. Majalah Ilmiah INTI (Informasi Dan Teknologi Ilmiah), 13, 125-132.

[7] Mahmudi Ali, Rokhman, Moh. Miftakhur, Prasetio, Achmat Eko. (2016). Rancang Bangun Sistem Pakar Untuk Mendiagnosis Tanaman Cabai Menggunakan Metode Bayes. Jurnal Ilmiah Rekayasa dan Manajemen Sistem Informasi. Vol 2, No 2.

[8] E, Turban. "Expert System and Applied Artificial Intelligence", Macmillan Publishing Company, New York, 1995.

[9] Kusrini. 2006. Sistem Pakar“Teori dan Aplikasinya”, Penerbit Andi. Yogyakarta.

[10] Prasetyo, Tri Ferga \& Iqbal, Muhammad (2017) Sistem Pakar Identifikasi Gaya Belajar Mahasiswa Berbasis Web. SeminarNasional Sains dan Teknologi 2016.

[11] Kenneth E. Kendall, Julie E. Kendall. 2010. Analisis dan Perancangan Sistem, Jakarta, PT Indeks.

[12] Merlina, Nita, Rahmat Hidayat. 2012. Perancangan Sistem Pakar. Ghalia Indonesia. Yogyakarta. 